\title{
To Whom Should I Send it? Sender Perspective on Incentivized Word of Mouth
}

\author{
Christiana Yosevina Tercia ${ }^{1}$, Thorsten Teicher ${ }^{2}$ \\ 1. Universitas Prasetiya Mulya, BSD City Kavling Edutown I.1, Jl. BSD Raya Utama, BSD City, Kec. Pagedangan, Tangerang, Banten 15339 \\ 2. University of Hamburg, Mittelweg 177, 20148 Hamburg, Germany
}

\begin{tabular}{l|l}
\hline A R T I C E IN F O & A B S R R C T \\
\hline $\begin{array}{l}\text { Keywords: } \\
\text { word of mouth, } \\
\text { consumer incentives, } \\
\text { tie strength, } \\
\text { mobile couponing }\end{array}$ & $\begin{array}{l}\text { This paper examines how consumers' WOM-related activity can be } \\
\text { steered by marketing measures. By conducting an experimental study } \\
\text { using mobile coupons as a novel tool of word of mouth, we specifically } \\
\text { investigate how monetary incentives foster senders' decision in targeting } \\
\text { Kata Kunci: } \\
\begin{array}{l}\text { dari mulut ke mulut, } \\
\text { insentif konsumen, } \\
\text { ikatan kuat, } \\
\text { kupon digital }\end{array}\end{array}$ \\
$\begin{array}{l}\text { incentivized WOM with receivers deemed to be close to them when } \\
\text { the amount of the incentive is unequal between sender and receiver, } \\
\text { and information on the incentive is revealed to both sides. The different } \\
\text { amount of incentive for senders and their receivers also leads senders to } \\
\text { target receivers who are deal prone. }\end{array}$
\end{tabular}

\section{SARI PATI}

Makalah ini membahas bagaimana aktivitas terkait WOM (informasi dari mulut ke mulut) konsumen dapat diarahkan oleh langkah-langkah pemasaran. Dengan melakukan studi eksperimental menggunakan kupon digital sebagai alat baru WOM, kami secara khusus menyelidiki bagaimana insentif moneter mendorong keputusan pengirim dalam penargetan penerima tertentu. Hasil penelitian kami menunjukkan bahwa pengirim cenderung berbagi pada WOM yang memiliki insentif, dengan penerima yang dianggap dekat dengan mereka yang jumlah insentifnya tidak sama antara pengirim dan penerima, dan informasi tentang insentif diungkapkan ke kedua sisi. Beda jumlah insentif bagi pengirim dan penerima mereka juga mengarahkan pengirim pada penerima target yang rentan dengan kesepakatan.. 


\section{INTRODUCTION}

Customer referrals can be the key in acquiring the right customers and maximizing customer lifetime value and thus can be of importance for firms' long-term profitability (Kumar, Petersen, and Lenoe, 2010). Word of mouth or WOM as one of customer acquisition tools contributes to $20-50 \%$ of all consumer purchasing decisions (Bughin, Doogan, and Vetvik, 2010). From the company's perspectives, WOM is highly relevant because consumer to consumer communication is deemed as more credible and trustworthy compared to traditional advertising initiate by the company (Trusov, Bucklin, and Pauwels, 2009). Given the importance of WOM, companies started to looking for ways to proactively manage and increase consumer involvement in WOM with incentive as motivators (Reimer and Benkenstein, 2018).

Through the development of mobile communication, researchers and marketers have recently enlarged the scope of WOM to become mobile WOM or $\mathrm{m}$-WOM. The transformation from WOM to m-WOM has enriched the possible media for consumers to express WOM. To provide a clearer description of m-WOM, Pousttchi and Wiedemann (2006) developed the Mobile Marketing Framework consisting of various techniques to conduct promotion through mobile devices. The objectives of mobile marketing include building brand awareness, changing brand image, promoting sales, enhancing brand loyalty, building customer database and make the information become contagious by utilizing mobile devices. Furthermore, Pousttchi and Wiedemann (2006) also stated that one of the tools of $\mathrm{m}-\mathrm{WOM}$ is mobile coupon or m-coupon.

M-coupon is defined as digital coupon sent to and store on mobile devices (such as smart phone) (Dickinger, A. and Kleijnen, M., 2008) and can be delivered by SMS text message or even in the form of QR code, which typically offers a price discount (percent - off, or "buy one get one free") that must be reedemed before an expiration date (Danaher et al., 2015). The flexible distribution, portability and accurate targeting become adventages of m-coupon (Banerjee and Yancey, 2010), therefore, according to Juniper Research (2018) the number of coupons redeemed in a form of $\mathrm{QR}$ code via mobile will reach 5.3 billion by 2022, up from an estimated 1.3 billion in 2017. Thus, with the rapid development of mobile technology, m-coupon become one of effective marketing tools in acquiring the right customers.

Consumers have various motives for becoming involved in WOM activities. One of the motive is economic, especially if there is an incentive involved in acquiring the coupon (Hennig-Thurau et al., 2004). Accordingly, companies regularly promote consumption by offering consumers with incentives to engage in WOM activity or called referral reward programs (Ryu and Feick 2007). Incentives can be utilized by marketers to create WOM, for example through coupons, thus, the critical question is whether to give an incentive to the sender (the customer who distribute or share coupon to others) or the receiver (the sender's contact and therefore the potential customer for the company) or both (Ahrens, Coyle, and Strahilevitz, 2012) Therefore, the design of WOM coupons, which can increase WOM, and the resulting redemption rate are important issues for a marketer, since company have budget limitation on promotion, thus it is important to optimize the allocation of budget.

In incentivized WOM, senders generally look for suitable receivers of incentivized WOM by making an implicit cost-benefit analysis which takes their sender-receiver relationship into account (Orshingher and Wirtz, 2018; Ryu and Feick 2007). Meanwhile receivers regardless their gender commonly concern about fairness of incentive provided for both sender and receiver (Tercia and Teichert , 2017). Therefore, as tie strength with receivers is one of the sender's considerations in determining suitable receivers (Brown and Reingen, 1987; Ryu and Feick, 2007), the distribution of incentive between sender and receiver also a 
critical condition that should take into marketer account (Tercia and Teichert, 2017).

To date studies on incentivized m-WOM particularly m-coupon as one of the tool have focused exclusively on m-coupon using behavior such as intention to redeem from the perspective of theory of planned behavior (Im and Ha, 2013; Achadinha, Jama, and Nel, 2014), technology acceptance model (Jayasingh and Eze , 2010), monetary value, emotional value and social value (Hsueh, and Chen, 2010), intrinsic and extrinsic motivation (Tang, Zhao and Liu, 2016) and those studies are focusing more on receiver perspective in redeeming m-coupon. Study which focusing on receiver as well as sender perspective on incentivized WOM done by Ahrens, Coyle, and Strahilevitz (2012) which suggested that the magnitude of financial incentives, and the relative magnitude of the incentives for the senders and receivers both influence e-referral rates. Thus, it is important for the company to arrange the distribution of incentive between sender and receiver to increase the referral rate from sender and response rate from receiver

The magnitude of incentive between sender and receiver is based on the notion that people are utility maximizer who make decisions in their own self-interest and people will be more motivated to do something if they are offered a larger number to do so (Levitt and Dubner, 2005). However based on equity theory, Walster, Berscheid, and Walster (1973) described that individual in general seek equity in what they give and what they receive. Moreover, considering utility maximiser and equality, Ahrens, Coyle, and Strahilevitz (2012) stated that the magnitude of incentive between sender and receiver can be in a form of sender and receiver receive the same amount of incentive, sender obtain incentive higher than receiver, or sender receive incentive less than receiver.

Furthermore, according to Ryu and Feick (2007), the perception of cost and benefit is a common situation in the sender -receiver relationship , consequently, senders will be more concerned about a possible negative impression as they potentially might be perceived as greedy (Xiao et al, 2011). Thus, targeting suitable receivers becomes the senders major concern particularly when the incentive information are being revealed by the company. Previous study also suggested that tie-strength plays an important role as the basis for social context in WOM activities (Brown and Reingen, 1987; Ryu and Feick, 2007). Hence, tie-strength with the receivers becomes one of senders ' considerations when determining the suitable receiver.

Another consideration related to the magnitude of incentive between sender and receiver is the company's policy on disclosing or not disclosing the proportion of incentive for both sender and receiver. According to Foreh and Grier (2003), the transparency on the monetary incentive will gives an impression that the senders who disseminating WOM content are an honest person and they do not have any hidden agenda. This perception will be positively responded by the receivers, compared to the situation where no information in the monetary incentive. The argument by Foreh and Grier (2003) is different to that of Campbell and Kirmani (2000), Kirmani and Zhu (2007), and Williams et al. (2004). They argue that with the transparency of incentive information, there is a trend that receivers will perceive that senders do not have a positive motive for forwarding M-WOM content and only do it to reap a fortune. Thus, there is a complex consideration from senders in targeting receivers of incentivized WOM in transparent condition.

With the aim to obtain a better understanding of the sender perspective of incentivized WOM, thus, this paper addresses the following research question "to whom should the sender send the m-coupon?" To answer that question, the experimental study was conducted by considering, first, the magnitude of incentive. Second, the transparency of incentive information provided for sender and receiver. Third, the tie-strength that the sender has with receiver and lastly, since we used m-coupon as the 
experimental object, thus, it is important to consider also receiver's deal proneness character.

\section{Literature Review}

Monetary incentives are widely used by marketers to encourage consumers to generate WOM (Tuk 2008). Consumers can get monetary rewards through e-coupons or M-coupons by providing the names and or addresses (e.g., email address) of their friends whom they consider to be potential customers of the relevant marketing company. Furthermore, according to Buhler (1992), those rewarded for their actions are more likely to behave the same again in the future. In line with Tuk (2008) and Buhler (1992), Gupta and Shaw (1998) argue that monetary incentives can be used to develop a certain behavior

A previous study by Ahrens, Coyle, and Strahilevitz (2013) on sender-receiver relationships proposed that the "reward both" strategy of providing the sender with a bigger share of the incentive than the receiver would result in more referrals being made by the sender. However, it is still unclear to whom the sender will share incentivized WOM particularly if the amount of incentive are different between sender and receiver. Furthermore, Tercia and Teichert (2017) uncover that receivers will have an unfavorable attitude if they received an m-coupon with an incentive that they obtain incentives smaller than the incentive obtained by the sender.

The relationship between senders and receivers in WOM activities, whether incentivized or nonincentivized, is an important factor and receives significant attention from some firms. In each WOM activity, a consumer can interact with many parties with various tie strengths (i.e., from strong ties (family) to weak ties (friends and acquaintances) (Wirtz and Chew, 2002). Hereby, the power of interpersonal ties is characterized by a combination of time, emotional intensity, intimacy, and the reciprocal relationship in the tie (Granovetter 1973). According to Bruyn and Lilien (2008), tie strength between senders and receivers in WOM activities plays an important role during the initial stage of word of mouth. In this stage, the receivers will perceive the WOM message to be more trustworthy and less risky if they received it from a sender with whom they have a strong tie relationship compared to a sender with whom they have only a weak tie relationship.

One reason senders disseminate particular WOM content to suitable receivers is that they want to strengthen their relationship with the receivers. A research conducted by Wirtz and Chew (2002) connecting WOM with relational ties from the sender's point of view concludes that consumers were more likely to generate WOM to strong ties than to weak ties particularly related to the dissatisfied experience. Furthermore, Frenzen and Nakamoto (1993) state that senders tend to send something with high economic value to receivers with whom they have a strong relationship. However in the case of incentivized WOM, impression management become one of sender's concern and according to Xiao et al., (2011) sender want to be perceived as helping a friend instead of take an advantage when incentive involve.

Additionally, sender is concern more on impression management when he/she deals with weak tie compare to the strong tie (Ryu and Feick 2007, Tuk et al. 2009). Receiver comes from the strongtie relationship spectrum are unlikely to have a negative impression to the sender even though incentive involved in the WOM activity. In regards to the magnitude of incentive, to Xiao et al., (2011) only suggested to reward both sender and receiver, to reward only the sender or to give reward only to receiver, thus it is interesting to understand more on the possibility of sender's action when there is magnitude of incentive between sender and receiver. Hence, this leads to the following hypothesis:

H1: When the amount of incentive is different between sender and receiver (i.e., sender get incentive bigger than receiver), the sender tends to choose a receiver with whom he/she 
has strong ties.

As Xiao et al. (2011) state, senders' decision to target suitable receivers becomes even more important when an incentive is involved in WOM activity because the sender has to consider the receiver's impression in order not to be perceived as a greedy person. Therefore, in incentivized WOM, and particularly if the incentive information regarding the different amount of incentives between each sender and each receiver is disclosed by the issuing company, senders will decide more carefully about which receivers are suitable in the process of incentivized WOM. The sender might have to consider the impression the receiver gets and how the latter will respond to this WOM (Jin, and Huang, Y., 2014; Ryu and Feick, 2007; Xiao et al., 2011; Wirtz et al., 2013). In addition, Tuk (2008) argues that the transparency/non-transparent condition is very much influenced by the relationship between senders and receivers. In the relationship with a friend, a colleague, or even an acquaintance, if the transparency condition is activated, receivers will perceive senders as sincere persons. However in the relationship with business relationship or Tuk (2008) called it as "Market Pricing" relationship, if transparency condition is activated, receivers will perceive senders to be opportunistic.

However, when sender feels psychological close to the receiver, he or she will be more other-focused and experience a sense of responsibility toward others (Clark, Fitness, and Brissette, 2001). However, sender will also consider not upsetting receivers they are close to. Those situations directed senders to choose receivers from a particular relationship, and leads us to the following hypothesis:

H2: The relationship between incentive differentiation (sender get incentive more than receiver) and tie strength between senders and receivers is moderated by transparency. Senders prefer to choose receivers with whom they have strong ties under transparent conditions.
To spread information quickly to as many people as possible and to acquiring new customers become the major objectives of firm-generated WOM (Stephen et al., 2012). In order to achieve these objectives, targeting the suitable people who have a high probability to become new customer is the key. In addition to the tie-strength factors when it comes to determining the most suitable receivers, sender has to consider receivers who are inclined to seize deals. Or else receiver who has deal-prone character. Deal proneness has been defined in different ways; for instance, Lichtenstein et al. (1990) define deal proneness as "an increased propensity to respond to a purchase offer because the form of the purchase offer positively affects purchase evaluations." While Thaler (1985) states that a deal prone person will purchase something just because it is a deal, regardless of whether the product is needed or not. In analogy hereto, we define receivers as deal prone if they are perceived to likely use the incentive they receive (e.g., redeem the coupon).

Concerning the unevenly split of incentive between sender and receiver, when sender get incentive more than receiver, senders are concern more about how receivers will perceive them (Xiao et al., 2011). However, besides of the receivers impression on senders, we have to consider also the possibility that the receivers` likelihood to seize deals also become senders` considerations when targeting the possible receivers. As deal prone receiver are likely will to have positive response on deal, thus, for them, seize a deal is matter more than impression that she/he has to the sender. Therefore, we propose the following hypothesis:

H3: When sender obtains incentive more than receiver, he/she tends to send M-coupons to deal prone receivers.

Furthermore, according to Tercia and Teichert (2017), receiver will develop an unfavorable attitude towards unevenly distributed incentive between sender and receiver (sender obtained incentive more than receiver) and unfavorable 
attitude ultimately will lead to negative intention to redeem the m-coupon. Given the possibility that the information about the unevenly distributed incentive between sender and receiver is passed on to the receiver, reducing a negative impression by targeting deal prone receivers is a solution for the sender, as Lichtenstein et al. (1990) state, deal prone consumers are likely to use the incentive they received, thus the sender can expect that even though the incentive is unequally distributed, the receiver will use it anyway. Therefore, we propose the following hypothesis:

H4: The relationship between incentive differentiation (sender get incentive more than receiver) and the receiver's deal prone character is moderated by transparency. In a transparent situation, the sender will focus more on targeting a deal prone receiver

\section{METHODS}

Our experimental study aims to investigate all four hypotheses $\mathrm{H} 1$ - H4 . This should provide a basis for understanding the influence of senders' decision to share an M-coupon with a particular receiver based on the tie strength they have and also on the deal proneness of the receiver.
We conducted a $2 \times 2 \times 2$ experimental design with the intention of testing the hypotheses. We manipulated the variables incentive differentiation (different versus no different) and incentive transparency (transparent versus non-transparent). Furthermore, we utilized two product categories (McDonald's versus Starbucks) as prototypical examples in our experiment study. As we are interested in generalized results, we do not differentiate results between these two product categories.

\section{Procedures and Scenario}

The survey consists of a simulated WoM situation which is described in consecutive sections. In the first section, we retrieve the names of weak and close partners of respondents using the "mentioning name" method. Based on Granovetter (1973), participants are asked to mention two persons each for two joint activities typically linked with strong ties (talk about personal matters, looking after an apartment during leave, asking for money), and two questions typically linked with weak ties (casual conversation; job or school assignments). This leads to eight names, which later represent the simulated receivers of M-coupons.

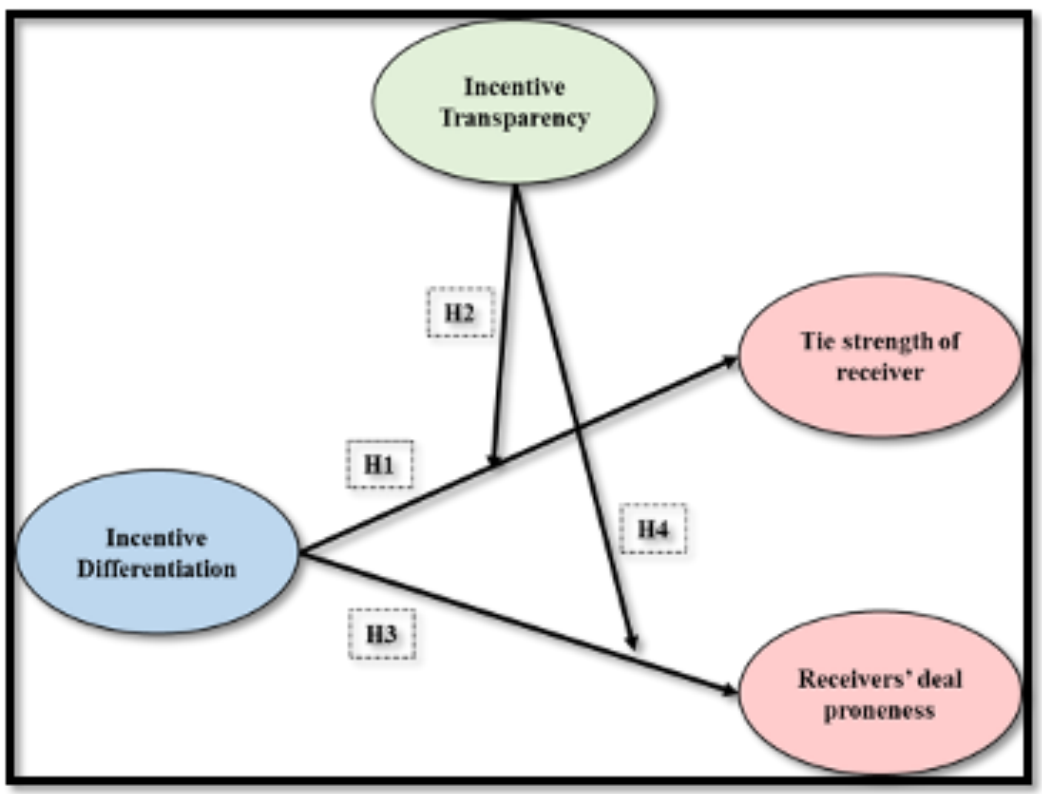

Figure 1. Research Model 
In the next section, participants are asked to justify the degree of closeness between participants with each of the names mentioned in Section One. Closeness is measured by asking the question, "How close do you feel to this person?" and applying a five-point Likert scale to the answers, which include: not close at all (1); not close (2); neither distant nor close (3); close (4); and extremely close (5),

In addition to the measurement of closeness, the participants are also asked for their opinion regarding the deal proneness of the individuals mentioned in Section One. The measure of deal proneness construct consists of three items adapted from Lichtenstein et al. (1990): "this person" is a person who enjoys looking for a discount offer; "this person" is a person who enjoys using a discount, regardless of the amount he/she can save from doing so; "this person" is a person who is more likely to buy a brand that offers a discount.

In the last section, each participant received eight relevant M-coupon scenarios which systematically varied incentive as an independent variable: Incentives were either equally distributed between sender and receiver or split unevenly, with the sender receiving the larger share of incentive, and the information regarding the amount of incentive the sender obtained either being known by the receiver or not. A balanced incomplete block design varied the sequence of both product categories (McDonald's and Starbucks). This ensured that participants had a balanced perception without encountering fatigue effects due to several repetitions.

The scenarios were presented in a realistic visualization (Figure 2). In every scenario the participants were not only shown their M-coupon, but also the M-coupon destined for their receivers if they decided to forward it. We asked participants in the role of senders to identify the most suitable receiver for each particular M-coupon, based on the eight names they had mentioned in Section One. These eight names appeared automatically as possible answers in every scenario, and the participants were simply required to choose one answer. They were free to choose the same name of the receiver in different scenarios and we randomized the order of the alternative answer in every scenario.
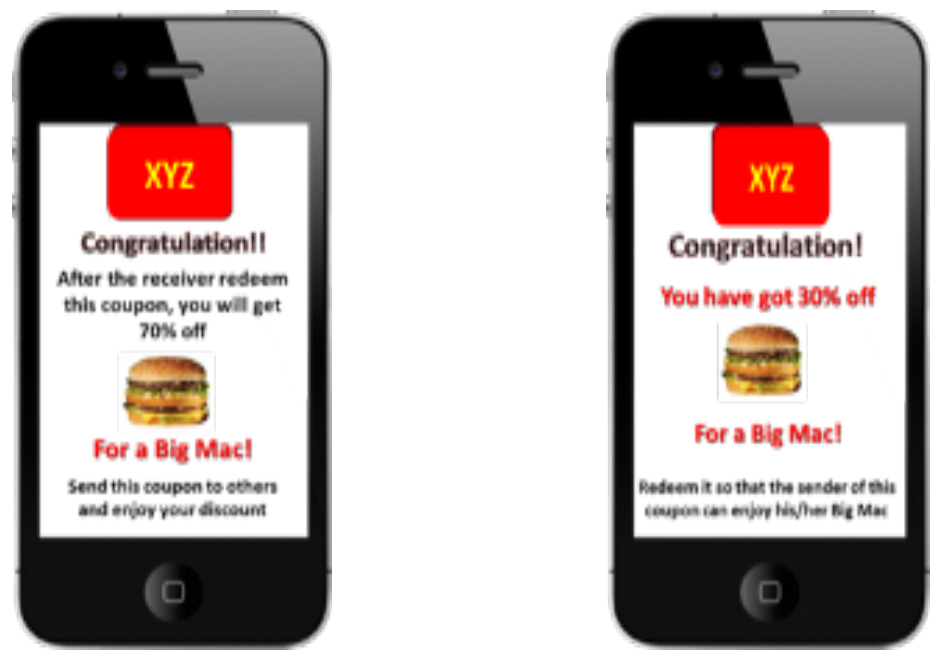

Figure 2. An example of a scenario from the senders' perspective

You received an M-coupon directly from McDonald's, exactly as illustrated in the picture below, with the following condition: After you send this M-coupon to another person and that person redeems it, you are entitled to a discount.

The discount you obtain will be higher than the discount the receiver will get, and the receiver will not get any information regarding the different 2amount of incentive between sender and receiver 


\section{Data Collection and Measurement}

In a research project, data were collected by an online survey from 85 participants recruited from university environments in Germany (43) and Indonesia (42). Each respondent participated in eight scenarios; therefore, after the manipulation check, we obtained 424 responses from both respondent groups. The following analysis merges the data between the German and Indonesian groups. The decision to merge the data between the German and Indonesian samples was supported by the result of an invariance test. A MANOVA analysis was conducted using the deal proneness and tiestrength of receiver as dependent variables.

Deal proneness of targeted receivers averaged 3.44 on a scale ranging from 1 to 5 (std.dev. 0.83 ), implying that the receivers on average were considered to somehow deal prone. Average tie strength of selected receivers amounts to 4.22 (std. dev. 0.72) which resembles the fact that people tend to communicate more with strong than with weak ties. While these absolute numbers are not as informative as such, the differences between the experimental conditions build the basis for the following analyses. Here, an eyeballing already unveils interesting patterns hinting towards limited contingencies according to the proclaimed hypotheses.

\section{FINDINGS}

We tested our hypotheses using MANOVA, with incentive differentiation as the independent variable, incentive transparency as a moderating variable and the deal proneness and tie-strength of receiver as dependent variables.

We first examine the effect of incentive differentiation on tie-strength of selected receivers. Results show that senders share the m-coupon with receivers with whom they have relatively stronger ties, when the incentive offered to them is higher than the incentive offered to the receiver and when this incentive information is being revealed $(F(1,676)=$ $10.246, p=0.01$, please refer to figure 3 ). In contrast hereto, when the information is not being revealed, senders share their m-coupons containing different amount of incentives with receivers regardless of

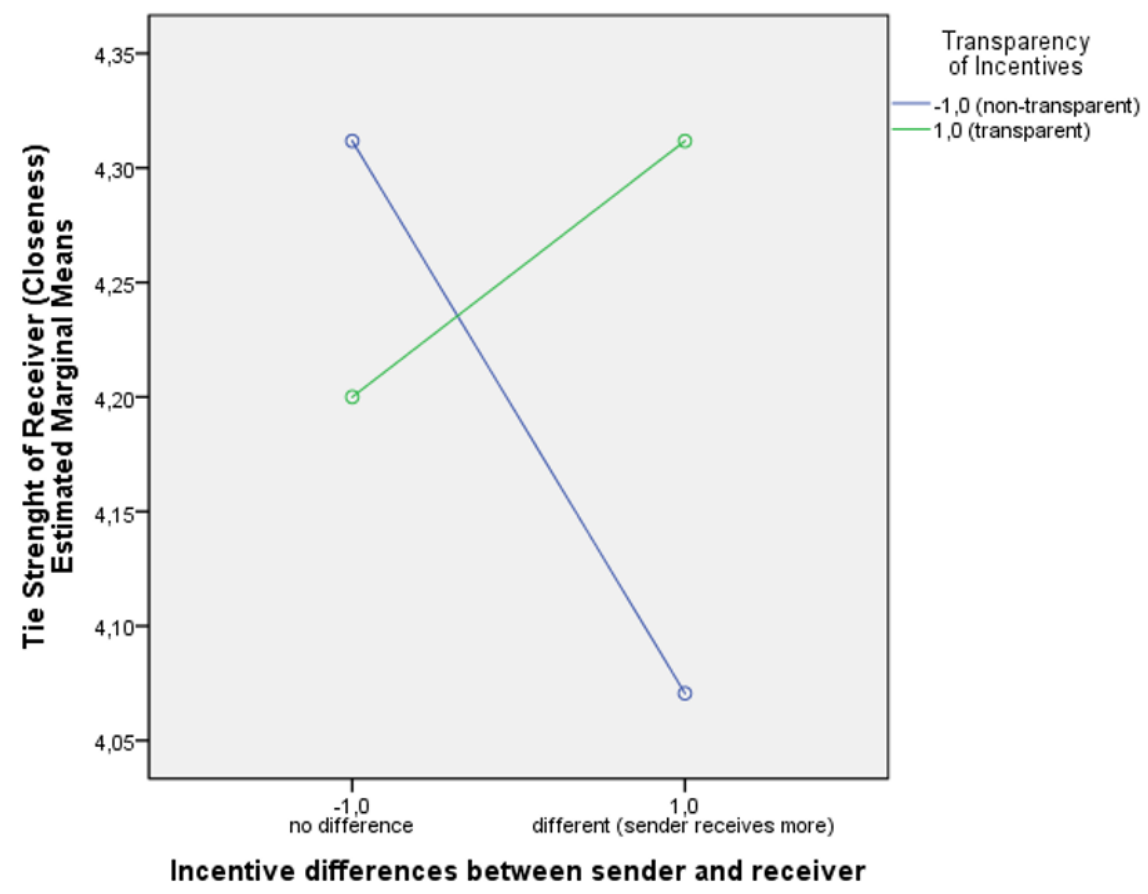

Figure 3. Estimated Marginal Means of Tie-strength of Receivers 
the tie-strength that they have with them, $\mathrm{F}(1,676)$ $=1.377, \mathrm{p}>0.1$, thus $\mathrm{H} 2$ is supported however this it is not the case for $\mathrm{H} 1$.

Regarding the effect of incentive differentiation on deal proneness of selected receivers, the experimental results suggest that senders will share coupons with receivers of high deal proneness, when they obtain a higher incentive than the receiver, $\mathrm{F}(1,676)=3.432, \mathrm{p}=0.06$, thus $\mathrm{H} 3$ is weakly supported. The effect however does not depend upon whether the incentive information is being revealed or not, $\mathrm{F}(1,671)=0.381, \mathrm{p}>0.1$. Hence, $\mathrm{H} 4$ is rejected (Please refer to Figure 4). Whereas senders react sensitively to the disclosure of unequal incentives when selecting receivers of weak or close ties, they disregard this condition in their choice of receivers of low or high deal proneness. They always select receivers with higher deal proneness if they sent coupons with fewer incentives provided to receivers as to themselves.

\section{DISCUSSION}

\section{Conclusion}

The focus of this study is senders' decision to choose suitable receivers of WOM with a particular design of the incentive components. The results in general show that senders tend to choose receivers with whom they have a strong tie relationship if information about the incentive obtained by both parties is revealed by the company.

However, in particular, the result indicates that if senders are asked to share an M-coupon with a differing incentive in it (i.e., the senders obtain a higher incentive than the receivers) and if information about the incentive is revealed to both sides, the senders will share this coupon with receivers with whom they have strong ties. The senders' decision to choose receivers with whom they have strong ties might be the result of the senders' consideration of impression that the receivers have as a result of receiving an M-coupon

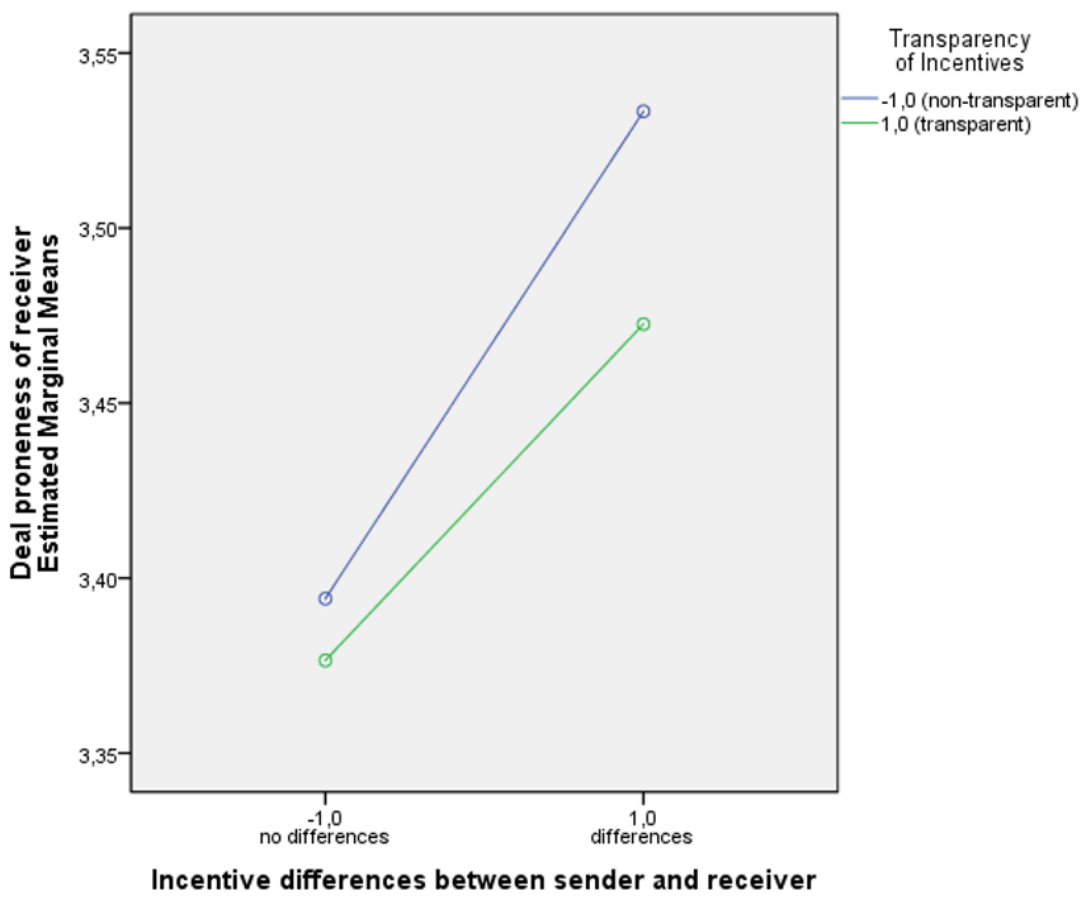

Figure 4. Estimated Marginal Means of Deal Proneness 
with an unequally shared amount of incentive (Ryu and Feick, 2007; Xiao et al., 2011).

However, little research has focused on consumers' deal proneness as a consequence or outcome. To complement previous research, this study explores receivers' deal proneness from the senders' perspective. It also relates this aspect to the different incentive components. With respect to an unequal incentive for senders and receivers (where receivers obtain a larger incentive), we discover that the senders focus on targeting deal prone receivers if this information is not disclosed to the receiving parties.

\section{Implications}

This paper contributes to the broad scientific literature and managerial issues by specifically investigating the relationships between senders and receivers in the context of incentivized WOM. Both tie strength and deal proneness of the targeted receivers are investigated as senders' choice in an experimental setting. Tie strength is a key factor when determining social relationships in incentivized WOM (Brown and Reingen, 1987; Ryu and Feick, 2007. Ryu and Feick (2007) find that rewarding both sender and receiver is particularly effective in order to increase referrals to receivers who have a weak tie relationship with the sender. Complementing this previous research, we propose a "reward both" strategy, including an unequally divided incentive between senders and receivers (where the reward for the senders is higher than that for the receivers). Our results show that a "reward both" strategy particularly steers senders to address strong tie receivers when information about their own incentive is made available to the receivers. Even though Tercia and Teichert (2017) stated that unevenly distributed incentive provided for sender and receiver will lead to receiver's unfavorable attitude, however, when the sender is come from the strong tie relationship spectrum with the receiver, usually receiver will not have a negative perception towards the sender (Granovetter 1973; Xiao et al., 2011).
The senders' decision on whom to send their M-coupons does not depend only on tie strength but is also steered by receivers' so-called "deal proneness" - i.e. the perceived propensity to utilize the received coupons. Deal proneness has been widely studied in the area of coupon usage (e.g., Bawa and Shoemaker, 1987; Bawa et al., 1997), particularly in the field of M-coupons (e.g., Banerjee and Yancey, 2010; Dickinger and Kleijnen, 2008). However, the importance of receivers' deal proneness in relation to the senders remains largely unexplored. What senders think about the receivers' deal proneness is important because, ultimately, receivers with high deal proneness are more likely to engage in incentivized WOM by redeeming their M-coupons. To tackle this lack of insight, our study also focuses on the impact of a differing incentive for both parties on the senders' decision to target receivers. We find that in "reward both" programs where senders obtain a higher incentive than the receivers, senders tend to send this M-coupon to deal prone receivers. Thus, this characterizes a situation of higher effectiveness for marketers' purpose of steering purchase actions.

Apart from contributing to scientific knowledge, findings have several practical implications. Firms must carefully establish a "reward both" strategy since a differing incentive potentially creates a feeling of unfairness for receivers. Therefore, the best strategy would be to provide the senders with a higher incentive than that offered to the receivers while not disclosing information thereon to the receivers. With such a strategy, firms could possibly acquire receivers who have a weak tie relationship with senders and also avoid the possibility that the receivers will have a negative attitude towards M-coupons. Besides, this strategy also leads senders to choose receivers who are deal prone. Thus, the probability that the receiver will redeem the coupon will be higher.

\section{Limitation and further research}

The findings of this study are subject to some limitation, and provide approach for future research. 
The first limitation is related to the samples used in this study. A convenience sample of university students is employed both in the pre-test as well as in the main study. Therefore, the generalizability of the findings is limited concerning the validity for all consumers. Accordingly, we suggest adding heterogeneity to the sample in future research. The second limitation of this study is that we focus more on the incentive in WOM without considering the importance of ethical issue particularly in the managerial implication which suggested that company should give incentive higher for sender without disclosing the incentive information. Thus, we suggest for the future research to considering the ethical issue applying in particular country.

REFERENCES

Achadinha, N.M.-J., Jama, L. and Nel, P. (2014). The drivers of consumers' intention to redeem a push mobile coupon. Behaviour and Information Technology, Vol. 33 No. 12, , 1306-1316.

Ahrens, J., Coyle, J., and Strahilevitz, M. (2012). Electronic word of mouth: The effects of incentives on e-referrals by senders and receivers. European Journal of Marketing, 47(7), S. 1034-1051.

Banerjee, S. and Yancey, S. . (2010). Enhancing mobile coupon redemption in fast food campaigns. Journal of Research in Interactive Marketing, Vol. 4 No. 2, 97-110.

Bawa, K., \& Shoemaker, R. W. (1987). The Coupon-Prone Consumer: Some Findings Based on Purchase Behavior across Product Classes. Journal of Marketing, 51(4), 99. doi:10.2307/1251251

Bawa, K., Srinivasan, S. S., \& Srivastava, R. K. (1997). Coupon attractiveness and coupon proneness: A framework for modeling coupon redemption. Journal of Marketing Research, 517-525.

Brown, J. J., \& Reingen, P. H. (1987). Social ties and word of mouth referral behavior. Journal of Consumer Research, 350-362.

Bruyn, A. de, \& Lilien, G. L. (2008b). A multi-stage model of word-of-mouth influence through viral marketing. International Journal of Research in Marketing, 25(3), 151-163.

Bughin, J., Doogan, J., \& Vetvik, O. J. . (April 2010). A new way to measure word-of-mouth marketing. McKinsey Quarterly, S. 113-116.

Buhler, P. (1992). The keys to shaping behavior. Supervision, 53(1), 18.

Campbell, M. C., and Kirmani, A. (2000). Consumers" use of persuasion knowledge: The effects of accessibility and cognitive capacity on perceptions of an influence agent. Journal of Consumer Research, 27(1), S. 69-83.

Clark, Margaret S., Julie Fitness, and Ian Brissette. (2001). Understanding People's Perceptions Relationships Is Crucial to Understanding Their Emotional Lives," in Blackwell Handbook of Social Psychology: Interpersonal Processes, Vol. 3. In Blackwell Handbook of Social Psychology: Interpersonal Processes, Vol. 3 (S. 253 - 278). Malden, MA: Blackwell.

Danaher, P., J., Smith, M., S., Ranasinghe, K., and Danaher T., S. (2015). Where, When, and How Long: Factors that Influence the Redemption of Mobile Phone Coupons . Journal of Marketing Research, 52, October, 710-25.

Dickinger, A. and Kleijnen, M. (2008). Coupons going wireless: determinants of consumer intentions to redeem mobile coupons . Journal of Interactive Marketing, Vol. 22 No. 3, 23-39.

Foreh, M. R., and Grier, S. (2003). When is honesty the best policy? The effect of stated company intent on consumer skepticism. . Journal of Consumer Psychology, 13(3), pp. 349-356.

Frenzen, J., \& Nakamoto, K. (1993). Structure, cooperation, and the flow of market information. Journal of Consumer Research, $360-375$

Granovetter, M. S. (1973). The strength of weak ties. American Journal of Sociology, 1360-1380. 
Gupta, N., \& Shaw, J. D. (1998). Let the evidence speak: financial incentives are effective!! Compensation \& Benefits Review, $30(2), 26-32$

Hennig-Thurau, T., Gwinner, K. P., Walsh, G., \& Gremler, D. D. (2004). Electronic word-of-mouth via consumer-opinion platforms: What motivates consumers to articulate themselves on the Internet? Journal of Interactive Marketing, 18(1), 38-52.

Hsueh, S.C. and Chen, J.M. . (2010). Sharing secure m-coupons for peer-generated targeting via eWOM communications. Electronic Commerce Research and Applications, Vol. 9 No. 4, pp. 283-293.

Im, H., and Ha, Y. (2013). Enablers and inhibitors of permission-based marketing: a case of mobile coupons. Journal of Retailing and Consumer Services, Vol. 20 No. 5, 495-503.

Jayasingh, S. and Eze, U.C. . (2010). The role of moderating factors in mobile coupon adoption: an extended TAM perspective. Communications of the IBIMA, Vol. 2010 No. 2010, 1-19.

Jin, L. and Huang, Y. (2014). When money does not work: The differential effects of monetary versus in-kind rewards in referral reward programs. International Journal of Research in Marketing, Vol. 31 No. 1, S. 107-116.

Juniper Research (2018). Mobile QR Code Coupon Redemptions to Surge, Surpassing 5.3 Billion by 2022: Fourfold Growth Driven by QR Reader Integration on Mobile devices. Retrived 22.12.2018. from: <https:/www. businesswire.com/news/home/20180103005014/en/Juniper-Research-Mobile-QR-Code-Coupon-Redemptions >

Kirmani, A., and Zhu, R. . (2007). Vigilant against manipulation: The effect of regulatory focus on the use of persuasion knowledge. Journal of Marketing Research, 44(4), S. 688-701.

Kumar, V., Petersen, J. A., \& Lenoe, R.P. . (2010). Driving profitability by encouraging customer referrals: who, when, and how. . Journal of Marketing, 74 (5), S. 1-17.

Lichtenstein, D. R., Netemeyer, R. G., \& Burton, S. (1990). Distinguishing coupon proneness from value consciousness: an acquisition-transaction utility theory perspective. The Journal of Marketing, 54-67.

Orshingher, C. and Wirtz, J. (2018). Psychological drivers of referral reward program effectiveness . Journal of service marketing, Vol. 32 No.3, 256-268.

Pousttchi, K. \& Wiedemann, D.G. 2006. A contribution to theory building for mobile marketing: Categorizing mobile marketing campaigns through case study research.[Online]. Available at: http://mpra.ub.uni-muenchen.de/2925/. [Accessed on 15 March 2018].

Reimer, T., and Benkenstein, M. (2018). Not just for the recommender: How eWOM incentive influence the recommendation audience. Journal of Business Research (86), 11-21.

Ryu, G., \&Feick, L. (2007). A penny for your thoughts: Referral reward programs and referral likelihood. Journal of Marketing, $71(1), 84-94$.

Stephen, A., Bart, Y., Du Plessis, C., and Goncalves, D. (2012). Does Paying for Online Product Reviews Pay Off? The Effects of Monetary Incentives on Consumers' Product Evaluations. INSEAD Working Paper No. 2012/96/MKT.

Tang, Q., Zhao. X. and Liu, S. (2016). The effect of intrinsic and extrinsic motivations on mobile coupon sharing in social network sites: The role of coupon proneness. Internet Research Vol. 26, No. 2, 101-119.

Tercia and Teichert . (2017). How consumers respond to incentivized word of mouth: An examination across gender. Australasian Marketing Journal (AMJ) 25 (1), S. 46-56.

Thaler, R. H. (1988). Anomalies: The ultimatum game. The Journal of Economic Perspectives, 195-206.

Trusov, M., Bucklin, R. E., and Pauwels, K. . (2009). Effects of word-of-mouth versus traditional marketing: Findings from an internet social networking site. Journal of Marketing, 73(5), 90-102.

Tuk, M. A. (2008). Is Friendship Silent When Money Talks? How People Respond to Word-of-Mouth Marketing (EPS-2008-130MKT): Erasmus Research Institute of Management (ERIM).

Walster, E., Berscheid, E. and Walster, G.W. . (1973). New directions in equity research. Journal of Personality and Social Psychology, Vol. 25 No. 2, 151 - 176.

Williams, P., Fitzsimons, G. J., and Block, L. G. (2004). When consumers do not recognize "benign" intention questions as persuasion attempts. Journal of Consumer Research, 31(3), S. 540-550.

Wirtz, J., \& Chew, P. (2002). The effects of incentives, deal proneness, satisfaction and tie strength on word-of-mouth behaviour. International Journal of Service Industry Management, 13(2), 141-162. doi:10.1108/09564230210425340

Wirtz, J., Orsingher, C., Chew, P. and Tambyah, S. (2013). The role of metaperception on the effectiveness of referral reward programs. Journal of Service Research, Vol. 16 No. 1, S. 82-98.

Xiao, P., Tang, C. S., \& Wirtz, J. (2011). Optimizing referral reward programs under impression management considerations. European Journal of Operational Research, 215(3), 730-739. 